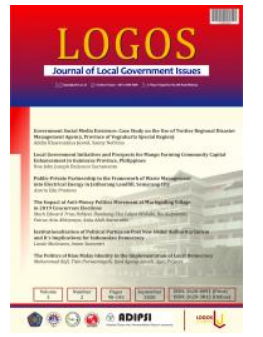

Volume 4 (2) (2021). 90-105

Journal of Local Government Issues

LOGOS

(LOGOS)

ISSN: 2620-8091 print | 2620-3812 online

Journal Homepage : http://ejournal.umm.ac.id/index.php/LOGOS/index

\title{
The Role of Women Village Heads in Decision Making Process in Lembung Timur Village
}

\author{
Nur Inna Alfiyah ${ }^{*}$, Dwi Listia Rika Tini² \\ 1,2Department of Public Administration, Faculty of Social and Political Sciences, Universitas \\ Wiraraja Sumenep \\ Jl. Raya Pamekasan - Sumenep No .KM, RW.05, Panitian Utara, Patean, Batuan, Sumenep, East \\ Java, Indonesia, 69451
}

*Corresponding author: nurinna@wiraraja.ac.id

\begin{abstract}
The election of a female village head in Lembung Timur is part of the maturity of the village community of Lembung Timur in seeing the meaning of gender equality in village leadership concerning leadership, especially in the decision-making process. Is it true that the appearance of a female village head to lead the village will be part of the better or more effective village leadership, which will lead to the decision-making process? This study aims to describe the role of female village heads in the decision-making process in Lembung Timur village, Lenteng district. The research method uses descriptive qualitative methods by utilizing qualitative data with descriptive elaboration. This study shows that, mainly in the decision-making process, Mrs. Faizah, as the village head in carrying out her role (manifest function), is only limited to the data collection stage. It can be said that Faizah has carried out her manifest function effectively because, from each stage of the decision-making process, she was done independently. The constraints faced are the lack of ability and experience and the occurrence of gender bias. Qualitatively, this study shows that the latent role or function of women's leadership in decision-making is not practical because the latent function performed in each decision-making process is played by Faizah's parents, namely Mr. Abdul Latif. Therefore, it is needed relating to the ability, skill, courage in playing the latent function for female village heads to break the hegemony of decision-making control by Mrs. Faizah's parents.
\end{abstract}

Article Info :

Article history :

Received : January 30, 2021

Revised:September 6, 2021 Accepted: September 20, 2021

Keywords:

lembung timur; female village head; decision-making; village administration

\section{INTRODUCTION}

Leadership is the ability of individuals to influence, motivate, and enable others to contribute to the effectiveness and success of the organization (Yuki, 2010; Cheong, 
Yammarino, Dionne, Spain, \& Tsai, 2019; Gardner, Karam, Alvesson, \& Einola, 2021; By, 2021). The primary key to success in leadership is respect for the leader (Rudolph, Katz, Ruppel, \& Zacher, 2020) so that compliance can be built (Garfield, 2019; Behrendt, Matz, \& Göritz, 2017). From this understanding of leadership, it can be concluded that the success of efforts to achieve organizational goals is determined by the existing leadership (Ford, Harding, Gilmore, \& Richardson, 2017; Rudolph et al., 2020), including when the crisis is in progress (Post, Latu, \& Belkin, 2019). In addition, in every organization, a leader is responsible for making decisions, but that does not mean that in carrying out the task of making decisions, a leader is alone without the help of others (Anthony \& Antony, 2017; Rosenhead, Franco, Grint, \& Friedland, 2019). In the decision-making process, a leader includes as many subordinates as possible and all levels of people in his environment so that decisions taken and mutually agreed upon can run well (Louis, 2015; Ospina, Foldy, Fairhurst, \& Jackson, 2020).

Leadership does not include gender as a requirement, but rather how to characterize a person to become an ideal leader (Harmer, Savigny, \& Ward, 2017). In Indonesia, research shows that women's leadership is quite successful (Da Meisa \& Anzari, 2021), although it is undeniable that patriarchism remains one of the biggest obstacles (Hamka, 2016; Sihidi, Khanifah, \& Romadhan, 2019; Muhajir, 2019). The same thing happened in Australia, Australia's first national paid, which succeeded in carrying out reforms (Newsome, 2017; Kakabadse, Tatli, Nicolopoulou, Tankibayeva, \& Mouraviev, 2018), in Canada, women's leadership in handling Covid-19 succeeded in controlling cases because of their strong resilience, emotion, and vulnerability (Cherneski, 2020). The key is women's self-leadership (Bendell, Sullivan, \& Marvel, 2019) and, most importantly, media framing to educate the public about the irrelevance of gender in leadership qualities (Bendell et al., 2019).

The development of the international world noted that there were important milestones that accelerated efforts to increase the position and role of women in decisionmaking or leadership. Among other things, by the stipulation of 1975 as the International Women's Year with the theme "Equality, Development, and Peace" and the period 19761985 designated as the United Nations decade for women and the 1995 Beijing Declaration, which stated that "Accelerate the implementation and seek strategies for the advancement of women and remove all obstacles and barriers to the active participation of women in all areas of public and private life through various fields such as economic, social, cultural and political decision-making." It is a significant commitment of all countries, including Indonesia, to uphold equality between men and women in all areas of life.

Indonesia, as a democratic country and universally respects human rights, does not recognize gender discrimination. In terms of positive law (UUD 45), no single article prohibits a woman from becoming a public leader of government organizations from the executive, legislative, and judicial levels to the lowest government organization, namely the village government. Thus, the role of women in Indonesian politics is no longer a "new thing" or a "taboo."

According to the Executive Director of the Indonesia Business Coalition for Women Empowerment (IBCWE), Maya Juwita revealed that Indonesia was ranked the fourth country with the most female leaders globally with $37 \%$ (Handayani, 2021). It is

\section{Journal of Local Government Issues (LOGOS), 4 (2), September 2021, pp 90 -} 105

ISSN : 2620-8091 print | 2620-3812 online 
evidenced by Indonesia being able to place women in strategic positions at various levels and sectors. At the central government level, out of 34 ministries, there are six ministries led by women, namely Minister of Foreign Affairs Retno Marsudi, Minister of Finance Sri Mulyani, Minister of Environment and Forestry Siti Nurbaya Bakar, Minister of Manpower Ida Fauziyah, Minister of Women's Empowerment and Child Protection Gusti Ayu Bintang Darmavati and the Minister of Social Affairs, Tri Rismaharini (Haryanti, 2019). At the regional level, such as East Java, it is led by a woman, namely Khofifah Indarparawansa. At the regency level, East Java is led by a woman, namely, Faida, Haryanti Sutrisno, Dewanti Rumpoko, Rukmini Buchori, Puput Trantiana Sari. The representation of women is also seen in Sumenep Regency, Madura, East Java, as seen from the representation of women in the legislature at 8 percent. Out of the 50 Sumenep DPRD, four of them are represented by women (Sumenep, 2020). Even at the village government level, Sumenep Regency shows that many women have succeeded in holding positions in the public sector as female village heads. It can be seen during the inauguration of the elected Village Head (Kades) in the 2019 simultaneous Pilkades in Sumenep Regency at the Pendopo Agung Keraton, Sumenep, of the 266 elected village heads, 39 people who elected are women. In the 2019 simultaneous village head elections, women's representation reached 18 percent in the village head elections.

(Pratiwi, 2019) sees that the 30\% representation of women's representation in political parties is not based on efforts to strengthen women's roles but rather on formalities. It is also related that women's leadership is not necessarily pro to women's interests, as in Bojonegoro (Prasetiawan \& Lis, 2019). In the field of education, women were found to be successful in leading educational institutions, namely Madrasah Aliyah in Bone Regency (Zakiah, 2018) in Islamic boarding schools (Prasetiawan \& Lis, 2019) and RA Nurus Salam Child-friendly schools, Sambirampak Kidul, Kotaanyar, Probolinggo (Baharun, Wibowo, \& Hasanah, 2021). In the field of village governance, several studies show how the leadership of female village heads works. In Ganting Village, Salo District, Kampar Regency, women's leadership as village heads who are intelligent, resilient, accountable, and innovative have succeeded in bringing progress (Ferta, 2020), although amid a strongly patriarchal culture. In the village of Purworejo, from Wates Blitar, the leadership of the female village head was successfully accepted by the opposing group because of her proactive leadership (Nursholikah, 2016). Similar findings also occurred in Bunder Village, Pamekasan Regency (Utaminingsih, Sabariman, \& Riniwati, 2020), Sumbermulyo Village, Bantul Regency (Asmara, 2020),and Banjarsari Village, Malang Regency (Sari, 2021). In contrast, in Lauran Village, the leadership of the female village head is weak due to the strong influence of interest groups and the strong patriarchal culture (Emanratu, 2021). The patriarchal culture has indeed become the biggest scourge of women's leadership which also occurred in the village of Maliki Air, Sungai Penuh City (Saputra \& Azmi, 2021) and in Nahdatul Ulama (NU) (Anshor, 2008).

Several previous studies generally looked at women's leadership in organizational structures and government institutions well. Women are considered to maintain a feminist character in leadership, such as being more nurturing to subordinates. Based on the previous research, there is still a scientific gap regarding the peculiarities of the form in the policy transition of male to female leaders. The majority of previous studies focused

\section{2 | Journal of Local Government Issues (LOGOS), 4 (2), September 2021, pp 90 -} 105

ISSN : 2620-8091 print | 2620-3812 online 
on the character of leadership, but none specifically revealed the transformation of male leadership into female leadership, especially in decision-making and the resulting policies.

However, despite the practice of feminine values from female leaders, they are still a minority group that tends to be subordinated in the decision-making process. As is the case in Lembung Timur Village, Lenteng District, Sumenep Regency, the author's initial observations found that decision-making in village government affairs cannot be done independently or so far even cannot be done by Mrs. Faizah as the village head. With subjective reasons, where the author has known and collaborated with the local community, it can be found that there are several reasons why this can happen. First, the village head admitted that she was still in the learning stage of leading the village, so she still felt unable to solve the many complex problems. Second, it is the villagers themselves who "do not want" her as the decision-maker.

The next problem concerns village leadership, especially in the decision-making process. Is it true that the appearance of a female village head to lead the village will be part of the better or more effective village leadership, which will lead to the decisionmaking process? It needs to be emphasized is how the role of female village heads in the decision-making process in the villages still needs to be questioned. However, a leader's leadership effectiveness can be measured by his accuracy and proficiency in taking or making decisions for his organization. This background makes the writer interested in researching women leaders related to the decision-making process in the village.

\section{METHOD}

The research method uses descriptive qualitative methods; descriptive is a method where researchers collect data, then analyze the data critically and conclude based on the facts at the time of the research. The purpose of descriptive research in this study is to describe and describe various facts and phenomena in the leadership of female village heads in the decision-making process. While the qualitative research method, according to Sugiyono, is the method used to examine the condition of natural objects, where the researcher is the key instrument by using triangular data collection techniques, namely a combination of observation, interviews, and documentation (Sugiyono, 2017). From the combination of this method, data collection was carried out by observation and interviews with seven informants consisting of core informants, specifically;

Table 1. Research Informants

\begin{tabular}{|l|l|l|}
\hline No. & \multicolumn{1}{|c|}{ NAME } & \multicolumn{1}{c|}{ POSITION } \\
\hline 1 & Faizah & Village Head \\
\hline 2 & Abd Latib & Former Village Head/Public Figure \\
\hline 3 & Salam & Village Secretary \\
\hline 4 & Hannan & Head of Rural Affairs \\
\hline 5 & Rasyid & Head of Rural Affairs \\
\hline 6 & Andi & Village Associate \\
\hline 7 & Kadir & Village's Consultative Agency (BPD) \\
\hline
\end{tabular}

Source: Researcher, 2020

93 | Journal of Local Government Issues (LOGOS), 4 (2), September 2021, pp 90 105

ISSN : 2620-8091 print | 2620-3812 online 
In addition to observation and interviews, the last technique used by researchers is documentation by referring to data collection methods through library studies such as archives, records, and documents, including work plans, village regulations, and the village head's manifest function.

\section{RESULTS AND DISCUSSION}

\section{Successful Decisions in Lembung Timur Village}

According to Eisenfuhr (Lunenburg, 2010), decision-making is the process of choosing from several alternatives to achieve the desired result. This definition has three key elements. First, decision-making involves choosing from several options. Second, decision-making is a process that involves more than just a final choice from among alternatives. Third, the "desired outcome" mentioned in the definition involves the goal or target resulting from the mental activity that the decision-maker is involved in reaching the final decision (Lunenburg, 2010). Decision-making, as in a village government organization, plays a significant role because the decisions taken by a village head are the final result that must be carried out by those involved in the village government organization. Many media are commonly used in decision-making. However, as far as the author knows, the media commonly used by government organizations, both central or national government organizations to village government organizations, is to use meeting media, both formally and informally. As in Lembung Timur Village, the media commonly used to make decisions are through two ways, namely formal meetings and informal talks.

As for one example of a decision that has been successfully taken in Lembung Timur village, both through formal and informal meetings, the following are examples of successful decisions taken, which the authors consider strategic decisions.

Tabel 2. Successful Decision Making Process

\begin{tabular}{|c|c|c|c|}
\hline Issue Definition & Actor Involved & $\begin{array}{c}\text { Decision Making } \\
\text { Process }\end{array}$ & Decision \\
\hline $\begin{array}{l}\text { This meeting is usually } \\
\text { held regularly every } \\
\text { month which the } \\
\text { government of } \\
\text { Lembung Timur } \\
\text { village carries out. This } \\
\text { planning meeting aims } \\
\text { to decide what work } \\
\text { plans will be carried } \\
\text { out for the next month } \\
\text { to get a clearer picture } \\
\text { for all village } \\
\text { governments } \\
\text { regarding what works } \\
\text { will be carried out and } \\
\text { whatachievements are } \\
\text { targeted for } \\
\text { completion for the } \\
\text { coming month. }\end{array}$ & $\begin{array}{l}\text { This work plan } \\
\text { meeting r was } \\
\text { attended and } \\
\text { carried out by } \\
\text { village government } \\
\text { administrators, } \\
\text { such as village } \\
\text { heads, village } \\
\text { secretaries, heads of } \\
\text { affairs, and heads of } \\
\text { hamlets. In this } \\
\text { meeting, village } \\
\text { officials function as } \\
\text { a transmitter of } \\
\text { input and as a } \\
\text { source of } \\
\text { information. This } \\
\text { information and } \\
\text { input are }\end{array}$ & $\begin{array}{l}\text { In this process, a village head is } \\
\text { required to be able to provide or } \\
\text { make choices. However, the } \\
\text { interviews with several } \\
\text { informants show that at the } \\
\text { work plan meetings that were } \\
\text { carried out, the village head still } \\
\text { often felt and experienced } \\
\text { confusion in finding or making } \\
\text { choices. In the end, no decisions } \\
\text { could be made at that time } \\
\text { (during the meeting). It was } \\
\text { constrained that Ms. Faizah, as } \\
\text { the village head, "did not act" } \\
\text { after the village officials } \\
\text { submitted the inputs. So that } \\
\text { Mrs. Faizah and village officials } \\
\text { always ask for the consideration } \\
\text { of Mr. Abd. Latib chose the }\end{array}$ & $\begin{array}{l}\text { Based on the interviews } \\
\text { from informants, } \\
\text { gathering input or } \\
\text { information was carried } \\
\text { out through a formal } \\
\text { meeting chaired } \\
\text { directly by Mrs. Faizah } \\
\text { as the village leader. } \\
\text { When it is her turn to } \\
\text { look for choices and } \\
\text { then decide what work } \\
\text { plans will be } \\
\text { implemented and } \\
\text { achieved for the next } \\
\text { month, it is not done } \\
\text { through a formal } \\
\text { meeting. Decision- } \\
\text { making at this work } \\
\text { plan meeting is carried }\end{array}$ \\
\hline
\end{tabular}

94 | Journal of Local Government Issues (LOGOS), 4 (2), September 2021, pp 90105

ISSN : 2620-8091 print | 2620-3812 online 


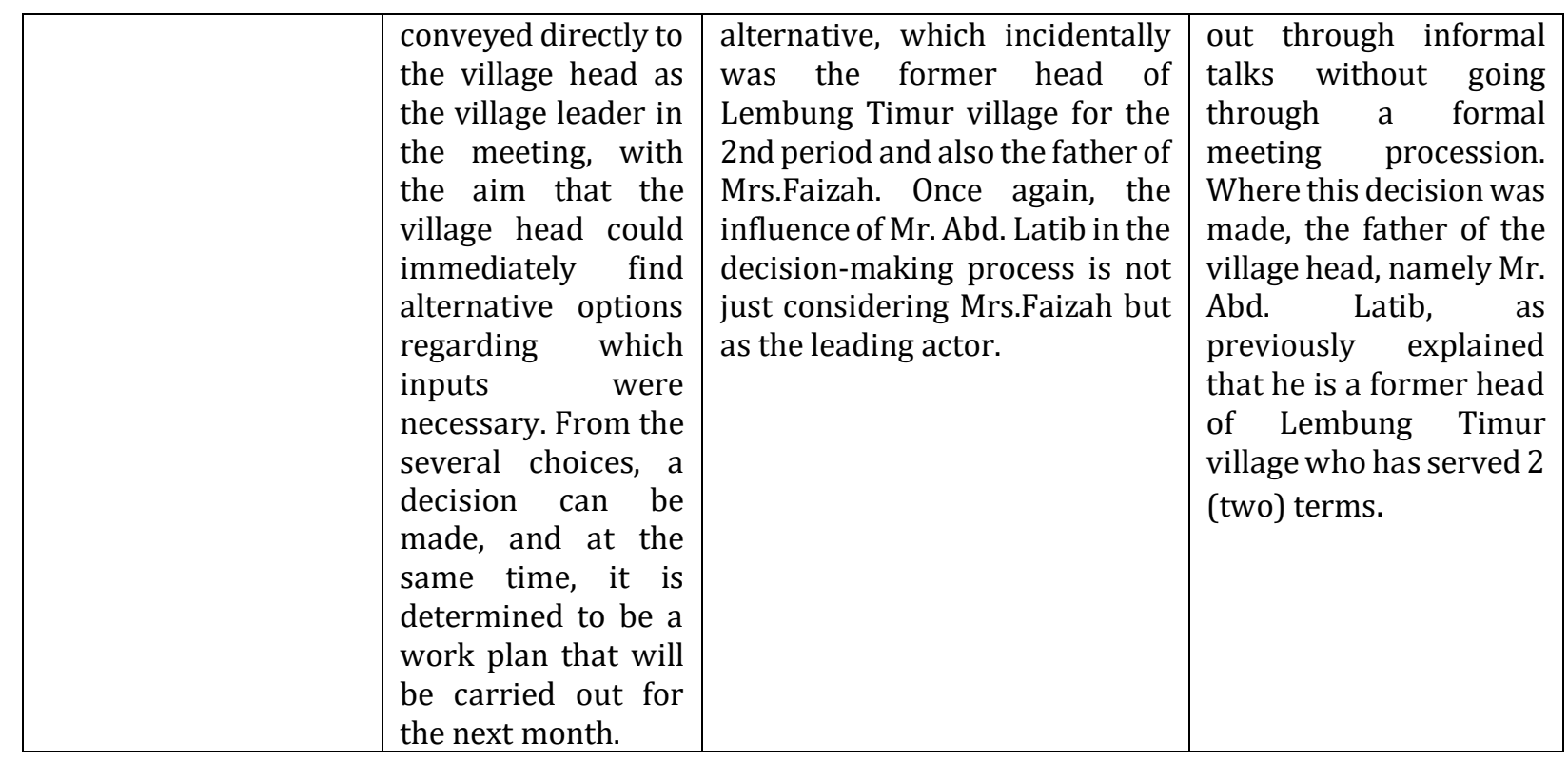

Source: Interviews from several informants such as Mrs. Faizah and the Village Apparatus on January 12, 2021, at 10.00 am

From the table 2, it can be concluded that the decision regarding what work plan will be carried out for the next month is the type of decision that must be taken and made manifest by Mrs. Faizah as the village head. This manifest function must be carried out by Mrs. Faizah in every stage of the decision-making process, starting from identifying the problem to making the final decision. However, the manifest function performed by Ms. Faizah in the work plan decision-making process turned out to be only at the stage of identifying problems and collecting data. The next procession or stage, precisely the stage of developing choices to making the final decision, is carried out in a latent function. It shows that the latent function in the decision-making process dominates more than the manifest process, which Mrs. Faizah should carry out as the village head, as seen in the table 3.

Table 3. The manifest Function by Mrs.Faizah

\begin{tabular}{|c|c|c|c|c|c|c|c|}
\hline \multirow[t]{2}{*}{$\begin{array}{c}\text { Decision } \\
\text { Type }\end{array}$} & \multicolumn{2}{|c|}{ Stages Of } & The & \multicolumn{2}{|c|}{ Decision-Making } & \multicolumn{2}{|c|}{ Process } \\
\hline & Identify Problem & Collecting data & $\begin{array}{c}\text { Developing } \\
\text { Alternatives }\end{array}$ & $\begin{array}{l}\text { Analyze and } \\
\text { evaluate } \\
\text { alternatives }\end{array}$ & $\begin{array}{c}\text { Dropping a } \\
\text { choice }\end{array}$ & $\begin{array}{c}\text { Analyze } \\
\text { possible } \\
\text { consequences }\end{array}$ & $\begin{array}{l}\text { Last } \\
\text { decision }\end{array}$ \\
\hline $\begin{array}{c}\text { Work } \\
\text { planning }\end{array}$ & Manifest & Manifest & Latent & Latent & Latent & Latent & Latent \\
\hline
\end{tabular}

Source: Researcher, 2020 
Tabel 4. Decision Making in Village Security Regulations

\begin{tabular}{|c|c|c|c|}
\hline Issue Definition & Actor Involved & $\begin{array}{c}\text { Decision Making } \\
\text { Process } \\
\end{array}$ & Decision \\
\hline $\begin{array}{l}\text { In August 2020, in } \\
\text { Lembung Timur } \\
\text { village, there were } \\
\text { frequent thefts at the } \\
\text { homes of residents. } \\
\text { Some of Lembung } \\
\text { Timur village people, } \\
\text { whether they were } \\
\text { victims of theft or not, } \\
\text { intensively tried to } \\
\text { discuss it informally to } \\
\text { find a solution so that } \\
\text { the incident would not } \\
\text { happen again in the } \\
\text { future. So the village } \\
\text { government makes } \\
\text { village security } \\
\text { regulations. The village } \\
\text { security regulation } \\
\text { aims to provide a sense } \\
\text { of security to the entire } \\
\text { community of } \\
\text { Lembung Timur } \\
\text { village. }\end{array}$ & $\begin{array}{l}\text { In making village } \\
\text { regulations, it must be } \\
\text { carried out by the } \\
\text { village head and the } \\
\text { Village Consultative } \\
\text { Body (BPD), where the } \\
\text { two elements are the } \\
\text { leading elements in the } \\
\text { village government. } \\
\text { However, it turns out } \\
\text { that the actors } \\
\text { involved in making } \\
\text { village in security } \\
\text { regulations in } \\
\text { Lembung Timur village } \\
\text { were not purely } \\
\text { carried out and came } \\
\text { from the initiative of } \\
\text { the two elements of the } \\
\text { village government } \\
\text { leadership. However, it } \\
\text { turns out that other } \\
\text { elements are also } \\
\text { involved and, at the } \\
\text { same time, greatly } \\
\text { influence the contents } \\
\text { of the village security } \\
\text { regulations that the } \\
\text { village head has agreed } \\
\text { upon and the Village } \\
\text { Consultative Body } \\
\text { (BPD), namely Mr. Abd. } \\
\text { Latib. }\end{array}$ & $\begin{array}{l}\text { Making Village } \\
\text { Regulations, a village } \\
\text { head has the initiative } \\
\text { right to submit a draft } \\
\text { village regulation, and } \\
\text { the Village } \\
\text { Consultative Body } \\
\text { (BPD), and the village } \\
\text { head has the initiative } \\
\text { right to submit a draft } \\
\text { village regulation. The } \\
\text { draft Security } \\
\text { Regulation in Lembung } \\
\text { Timur Village indicated } \\
\text { that the village head } \\
\text { proposed it. However, } \\
\text { from the results of } \\
\text { interviews with Mrs. } \\
\text { Faizah and Mr. Abd. } \\
\text { Latib pointed out that } \\
\text { the one who took the } \\
\text { initiative to draft } \\
\text { village security } \\
\text { regulations was not } \\
\text { Mrs. Faizah. However, } \\
\text { the initiative came } \\
\text { from her father's } \\
\text { thoughts by seeing the } \\
\text { condition of the village } \\
\text { and the complaints. } \\
\text { The draft village } \\
\text { regulation that Mr. Abd } \\
\text { has prepared. Latib } \\
\text { then brought Mrs. } \\
\text { Faizah to a formal } \\
\text { meeting to be } \\
\text { discussed and then } \\
\text { stipulated as a village } \\
\text { regulation together } \\
\text { with the Village } \\
\text { Consultative Body } \\
\text { (BPD). }\end{array}$ & $\begin{array}{l}\text { In order to create } \\
\text { security and } \\
\text { tranquility for the } \\
\text { Lembung Timur village } \\
\text { community, it is } \\
\text { considered necessary } \\
\text { to establish a village } \\
\text { security regulation. } \\
\text { The village security } \\
\text { regulations that have } \\
\text { been formed are valid } \\
\text { for all members of the } \\
\text { village community. In } \\
\text { addition, the village } \\
\text { security regulations } \\
\text { also apply to other } \\
\text { members of the } \\
\text { community who are in } \\
\text { Lembung Timur } \\
\text { village. As explained } \\
\text { earlier, the issue that } \\
\text { developed or became } \\
\text { the background for } \\
\text { forming this village } \\
\text { security regulation } \\
\text { was the frequent } \\
\text { occurrence of theft } \\
\text { cases. }\end{array}$ \\
\hline
\end{tabular}

Source: Interviews from several informants such as Mrs. Faizah, Mr. Abd Latib (Former Village Head), and Village Officials on 12 and 13 January 2021 at 09.00 am 
The table 4 shows that village security regulations are a form of regulation or legal product made by the village government. This type of decision (regulation) has the authority to take and make decisions, namely Mrs. Faizah manifestly as one of the elements of leadership at the village level. This manifest function must be carried out by Mrs. Faizah in every stage of the decision-making process, starting from identifying problems to making the final decision (determination). However, Mrs. Faizah, in carrying out her manifest function in making village security regulations, it turns out that it is only at the stage of making the final decision (determination). In a series of processions or previous decision-making stages, namely at the stage of identifying the problem to the stage of analyzing the consequences that may occur, it turns out to be carried out in a latent function as seen in the table 5.

Table 5. The manifest function of Mrs.Faizah

\begin{tabular}{|c|c|c|c|c|c|c|}
\hline \multirow[t]{2}{*}{$\begin{array}{c}\text { Decision } \\
\text { Type }\end{array}$} & \multicolumn{6}{|c|}{ Stage Of The Deci } \\
\hline & Identify Problem Collecting data & $\begin{array}{l}\text { Developing } \\
\text { alternative }\end{array}$ & $\begin{array}{l}\text { Analyze and } \\
\text { evaluate } \\
\text { alternatives }\end{array}$ & $\begin{array}{l}\text { Dropping a } \\
\text { choice }\end{array}$ & $\begin{array}{c}\text { Analyze } \\
\text { possible } \\
\text { consequence }\end{array}$ & $\begin{array}{c}\text { Last } \\
\text { decision }\end{array}$ \\
\hline $\begin{array}{l}\text { Regulation } \\
\text { of } \\
\text { Security } \\
\text { village }\end{array}$ & Latent & Latent & Latent & Latent & Latent & Manifest \\
\hline
\end{tabular}

Source: Researcher, 2020

Tabel 6. Decision Making in Village regulations regarding Village Revenue and Expenditure Budget (APBDes)

\begin{tabular}{|c|c|c|c|}
\hline Issue Definition & Actor Involved & $\begin{array}{l}\text { Decision Making } \\
\text { Process }\end{array}$ & Decision \\
\hline $\begin{array}{l}\text { Village regulations } \\
\text { regarding APBDes, are } \\
\text { a form of local legal } \\
\text { product that must } \\
\text { routinely be formed } \\
\text { and stipulated by the } \\
\text { village government. } \\
\text { APBDes is the primary } \\
\text { source in financing a } \\
\text { series of activities or } \\
\text { programs planned to } \\
\text { run the wheels of } \\
\text { village government } \\
\text { organizations. }\end{array}$ & $\begin{array}{l}\text { Making a village } \\
\text { regulation, whether it is } \\
\text { a village regulation } \\
\text { regarding the APBDes } \\
\text { or village regulations in } \\
\text { other forms, the actors } \\
\text { who always play a role } \\
\text { and have authority in } \\
\text { drafting its stipulation } \\
\text { are the village head and } \\
\text { the Village Consultative } \\
\text { Agency (BPD). From the } \\
\text { interviews with several } \\
\text { informants, the actor } \\
\text { involved in making } \\
\text { village regulations } \\
\text { regarding APBDes in } \\
\text { Lembung Timur village } \\
\text { is the village head with } \\
\text { the assistance of other } \\
\text { village officials and the } \\
\text { Lembung Timur Village } \\
\text { Consultative } \\
\text { (BPD). Body }\end{array}$ & $\begin{array}{l}\text { Looking at the results of } \\
\text { interviews that have } \\
\text { been carried out as a } \\
\text { whole, it can be } \\
\text { concluded that Mrs. } \\
\text { Faizah has a reasonably } \\
\text { active role in the } \\
\text { process of making } \\
\text { village regulations } \\
\text { regarding the APBDes. } \\
\text { Mainly from the start of } \\
\text { the process of } \\
\text { preparing the APBDes } \\
\text { draft to the process of } \\
\text { discussing and } \\
\text { determining the } \\
\text { RAPBDes to become } \\
\text { APBDes, In the process } \\
\text { of preparing this } \\
\text { RAPBDes, Mrs. Faizah } \\
\text { has a somewhat } \\
\text { important role, namely } \\
\text { determining how much } \\
\text { funds will be allocated }\end{array}$ & $\begin{array}{l}\text { Making RAPBDes in } \\
\text { Lembung Timur village } \\
\text { has taken almost two } \\
\text { months, where the } \\
\text { beginning of the } \\
\text { drafting process started } \\
\text { from mid-December } \\
2019 \text {, and then it was } \\
\text { mutually agreed } \\
\text { between the village } \\
\text { head and the Village } \\
\text { Consultative Agency } \\
\text { (BPD) on February 4, } \\
\text { 2020. Finally, in a series } \\
\text { of processions carried } \\
\text { out for two months, a } \\
\text { joint agreement } \\
\text { between the village } \\
\text { head and the Lembung } \\
\text { Timur Village } \\
\text { Consultative Agency } \\
\text { (BPD) was made in the } \\
\text { form of a village } \\
\text { regulation, namely the }\end{array}$ \\
\hline
\end{tabular}

97 | Journal of Local Government Issues (LOGOS), 4 (2), September 2021, pp 90 105

ISSN : 2620-8091 print | 2620-3812 online 


\begin{tabular}{|c|c|c|c|}
\hline & & $\begin{array}{l}\text { to run each program } \\
\text { that the head of } \\
\text { financial affairs has } \\
\text { successfully prepared. } \\
\text { Then in the following } \\
\text { process, namely the } \\
\text { discussion process, } \\
\text { Mrs. Faizah also has an } \\
\text { important role, namely } \\
\text { making a presentation } \\
\text { on the RAPBDes that } \\
\text { she has designed. }\end{array}$ & $\begin{array}{l}\text { Lembung Timur Village } \\
\text { Regulation, Lenteng } \\
\text { District, Sumenep } \\
\text { Regency Number } 1 \text { of } \\
2020 \text { concerning Village } \\
\text { Revenue and } \\
\text { Expenditure Budget. }\end{array}$ \\
\hline
\end{tabular}

Source: Interviews from several informants such as Mrs. Faizah and the Village Apparatus on January 12, 2021, at 10.00 am

From the table 6, it can be concluded that the role of Mrs. Faizah from each stage or decision-making process in making village regulations on the APBDes, turns out that Mrs. Faizah carries out the whole (step by step) in a manifest function. It shows that in making APBDes, Mrs. Faizah, as the village head, has carried out her function or role effectively. It can be described as follows:

Tabel 7. The Manifest function of Faizah's

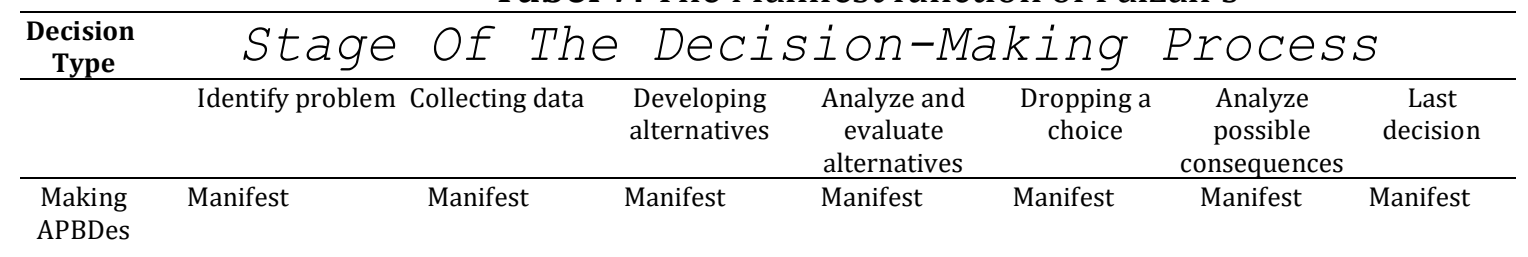

Source: Researcher, 2020

From the three types of decisions that have been researched and described above, it is clear that there is only one type of decision that can be taken and made by Mrs. Faizah as a village head independently through the manifest function, namely the making of Village Regulations on APBDes. The decisions that have been made in the village of Lembung Timur so far, which should have been the authority of Mrs. Faizah as the village leader and must be carried out with a manifest function, turn out to be many stages in the decision-making process that are still carried out through latent functions or roles.

\section{The Role Of Female Village Heads In The Decision-Making Process}

This paper refers to every type of decision that has been successfully decided in Lembung Timur village, both formal and informal meetings that have been described in the previous discussion to see how Mrs. Faizah is a village leader in the decision-making process. The types of decisions that have been successfully made in Lembung Timur village are taken through formal and informal meetings. Formal meetings are held regularly with a predetermined period to determine what monthly work program will be carried out. Then to stipulate village regulations regarding APBDes, it is also carried out regularly every year because the village regulations regarding APBDes are only valid for one year after the regulation is enacted.

98 | Journal of Local Government Issues (LOGOS), 4 (2), September 2021, pp 90 105

ISSN : 2620-8091 print | 2620-3812 online 
Based on the study results, it is clear that the data used as the basis for the decision-making process in the village of Lembung Timur were obtained from aspirations, input, suggestions, and information from village officials and village communities. The data in the form of aspirations, inputs, suggestions, and information submitted by subordinates as village officials and village communities will then be collected and used as the primary data in the decision-making process.

Making decisions regarding work planning and village security regulations shows that before a series of decision-making processes are carried out, the village head tries to explore and collect relevant data about the problems that Mrs. Faizah wants to solve as the village government leader. Also, one element of the leadership of the village government has succeeded in collecting data in the form of aspirations, input, suggestions, and information from the village community and other village officials. The data collection is carried out through formal and informal meetings. For example, they collect data in the decision-making process regarding work plans and making village security regulations. Mrs. Faizah usually does this data collection by recording all the inputs submitted by her subordinates.

If we look at the reality of the results of the research that has been done, it shows that in the stage of making choices as the third stage of a series of decision-making processes, Mrs. Faizah, as village head tends to be unable to carry it out. For example, in the decision-making process regarding the monthly work plan. In the decision-making process of the problem, the village head can only record input data collection. However, when it was her turn to make or provide choices, this could not be done by Mrs. Faizah as the village leader. It clearly shows that Mrs. Faizah, as the village leader, cannot provide choices to her subordinates in the meeting that is currently being held (ongoing) to make a decision.

As explained above, this research has shown that for the most part, in the decisionmaking process, Mrs. Faizah, in carrying out her role (manifest function), is only limited to the data collection stage. However, there is one type of decision that Mrs. Faizah has succeeded in taking and making through every stage of the decision-making process, namely the decision on village regulations regarding APBDes. In making this village regulation regarding APBDes, it can be said that Mrs. Faizah has carried out her manifest function effectively because each stage of the decision-making process is carried out independently. The study identified that Mrs. Faizah experienced several obstacles, both from herself (internal) and from outside (external). Therefore, for more details will be explained in detail as follows;

\section{Lack of Ability Factor (Capability)}

The study results indicate that Mrs. Faizah often feels doubtful and confused when making or providing choices. The doubt and confusion experienced by Mrs.Faizah emerged when she faced or received a lot of input, suggestions, and information submitted by her subordinates like village officials and village communities. If it is analyzed carefully, or at least it has been acknowledged by Mrs. Faizah herself that the feeling of doubt and confusion experienced in the meeting when making and providing choices is none other than the lack of experience.

99 | Journal of Local Government Issues (LOGOS), 4 (2), September 2021, pp 90 105

ISSN : 2620-8091 print | 2620-3812 online 
If we look at the biography of Mrs. Faizah, it can be seen that before Faizah became a village leader, it turned out that she never had experience in occupying strategic positions as decision-makers. Before becoming a village head, Faizah was involved in several organizations at the village and sub-district levels. For example, Mrs. Faizah was once an Integrated Healthcare Center (Posyandu) cadre at the sub-district level. Being an Integrated Healthcare Center (Posyandu) cadre whose capacity is only as an ordinary member is limited in the organization's authority, duties, and obligations.

In addition to the minimal background experience possessed by Mrs. Faizah, likely, Faizah's educational background is also one of the inhibiting factors for her to play a role in the decision-making process. If we look at her biography, Faizah is a woman who only has a high school education background. Indeed, the level of education is not an absolute measure to assess a person's ability. However, it has become a public image that the level of education shows personal qualities.

\section{There is a Gender Bias}

In reality, women leaders still face many challenges and obstacles that must be faced. It resulted in her not performing her leadership function as a female leader perfectly, especially to carry out her role in the decision-making process. It can be seen from the results of research that has been carried out, namely on female leaders at the village level in Lembung Timur village. The research that has been done shows that the behaviors that arise (such as doubt and confusion) experienced by Mrs. Faizah in leading a meeting to make a decision often arise because of the fear and lack of courage she was experiencing.

Doubt and confusion are experienced by Mrs. Faizah as a village leader when in the decision-making process, resulting in her being considered indecisive, not having the courage, being unresponsive, not quick and precise by her subordinates. Even worse, village officials and village communities think that Mrs. Faizah likes not being assertive, brave, quick and responsive, and others. As a characteristic of women.

With the "labeling" of these female traits to Mrs. Faizah, the village officials and the community did not allow her to make choices and make decisions about the problems currently being discussed in the meeting. Mrs. Faizah often feels doubt and confusion in meetings, resulting in her not being too trusted to make decisions on the problems faced in her village. What needs to be emphasized in this case is that she is not given the opportunity and trust as a female leader in the decision-making process due to the labeling of "negative" traits by village officials and the community, where these traits are often identified with character possessed by women in general. The labeling of negative traits that are identified as female traits causes people to no longer trust Mrs. Faizah in terms of decision making, and it is assumed that female leaders cannot be assertive, do not have the courage, are less quick and responsive, do not want to take risks, and often face confusion. This kind of situation can finally be called gender bias, where the existence of this gender bias then becomes one of the obstacles for her to carry out her manifest function in the decision-making process.

In this study, it can be concluded that Mrs. Faizah in the decision-making process, her manifest function is only at the level of collecting input, suggestions, and information

100 | Journal of Local Government Issues (LOGOS), 4 (2), September 2021, pp 90 105

ISSN : 2620-8091 print | 2620-3812 online 
from her subordinates, from now on referred to as the processor stage of data collection only. It can happen because internal factors hamper it. Specifically, the lack of ability of Mrs. Faizah, both in terms of experience and education, is also caused by external factors, namely the existence of gender bias in the lives of the Lembung Timur village community, where the female leader is considered unable to be assertive, weak, courageous, and shrouded in fear. These assumptions then resulted in Mrs.Faizah being distrusted and not allowed to play a role in the decision-making process or even as a decision-maker.

It has clearly shown that a latent function is carried out in the decision-making process, both formally and informally. The latent function referred to here is a function or role not carried out by Mrs. Faizah but is a function or role carried out by people outside the applicable provisions who have no legitimacy and are outside the village government institution or organization. This latent function is performed by none other than her father, Mr. Abd. Latib, a former head of Lembung Timur village who has served for two consecutive terms. Based on the results of the study, it shows that the latent function (role) played by Mr. Abd. Latib has more power in the decision-making process, especially in the manifest function, than Mrs.Faizah. The graph below shows how Abd carries out the dominant role of latent functions. Latib in the decision-making process and haw the manifest role carried out by Mrs. Faizah.

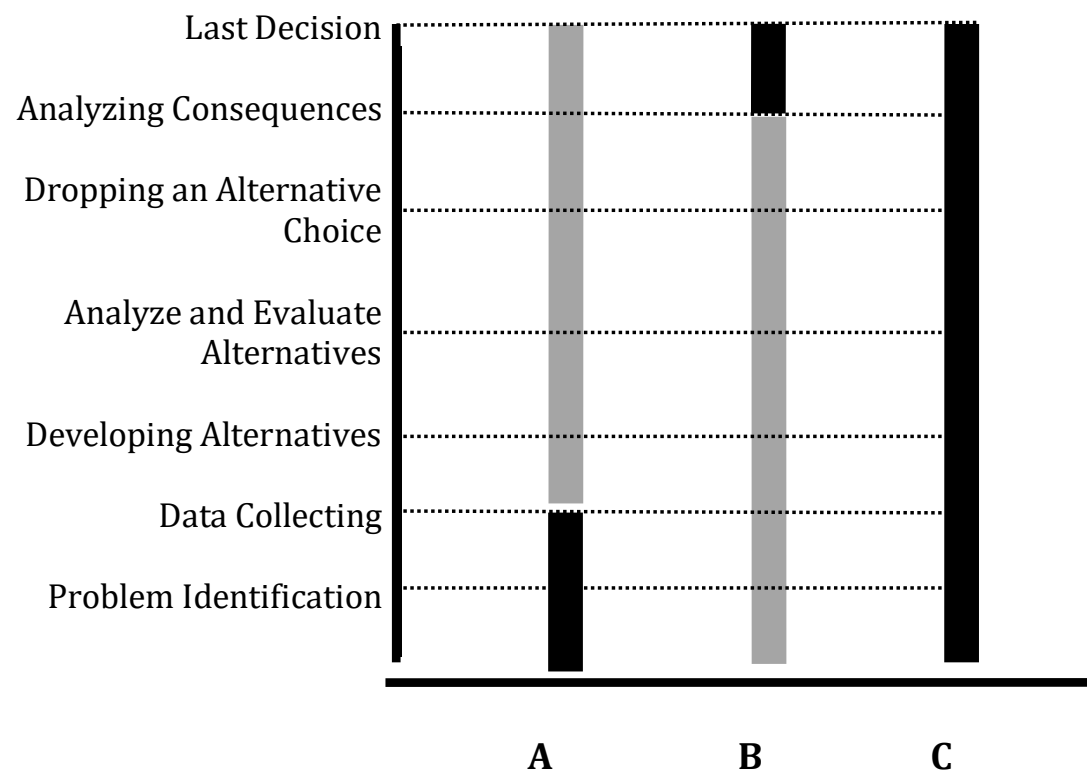

Figure 1. Graph of Manifest Function and Latent Function in the decision-making process

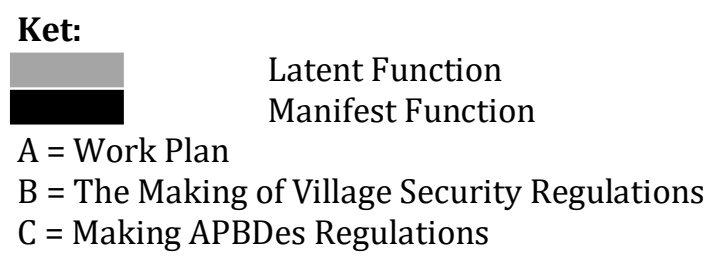

101 | Journal of Local Government Issues (LOGOS), 4 (2), September 2021, pp 90 105 
The graph (Figure 1) described above has clearly shown that the latent function is more dominant (active) and the manifest function played by Mrs.Faizah is less active (passive). According to the study results, from the description above, it is indeed a latent function played or carried out by Mr. Abd. Latib in the decision-making process is not only due to the inability of Mrs. Faizah and the existence of gender bias, but other factors underlie Mr. Abd. Latib plays their role in the decision-making process, both roles that are merely influencing and the leading actor in making decisions as described previously. Another factor referred to here is the hegemony of power that Mr. Abd is carrying out. Mr. Abd. Latib as a former village head.

The assumption is that the background of Mrs. Faizah's emergence as village head is the result of engineering. The engineering in question is that Mrs. Faizah is only used as a "tool" by Mr. Abd. Latib to maintain his power. With this condition, Mr. Abd. Latib will still be able to influence and control the subsequent administration of Lembung Timur village. It is also reinforced by the research results, both through interviews and observations that have been made. The results showed that after Mrs. Faizah's succeeded in serving as village head, she was never separated from the influence and control of her father. Mr. Abd Latib plays the dominant role in the latent function of the decision-making process is then identified as a form of the hegemony of power.

\section{CONCLUSION}

One of the desires that the women's movement wants to fight for is the increase in female leaders and the opening of opportunities for women to participate in decisionmaking, which men have dominated. When speaking in Lembung Timur village, women have an excellent opportunity to play a leadership role, seeing that the number is quite large compared to men. In addition, the Lembung Timur village community has also begun to elect women leaders openly. However, Mrs. Faizah has carried out as a leader for the first time in Lembung Timur village; the opportunity is not followed or balanced by her qualities and abilities. Opportunities for women to become leaders who are not followed by qualified abilities will hinder them in carrying out their roles as decisionmakers. Her inability to make decisions in the village is inevitable that it will also hamper development in the Lembung Timur village, which she is currently leading.

If we look back at the results of the research that has been done, it turns out that female leaders are also still considered as the second person (subordinate) in the field of decision making, where women are considered to be indecisive, not creative, not agile, not fast and firm in making decisions. The hegemony of power carried out by the person in power before, such as Mr. Abd Latib, is also a dominant inhibiting factor and provides limitations for women like Mrs.Faizah always to exist and be independent to play a role in the decision-making process. So, it can be concluded that Mrs. Faizah, as village head, is not effective in carrying out her leadership function. It can be concluded when viewed from how the role played by Mrs. Faizah in the decision-making process is very minimal, as described in detail above.

102 | Journal of Local Government Issues (LOGOS), 4 (2), September 2021, pp 90 105

ISSN : 2620-8091 print | 2620-3812 online 


\section{REFERENCES}

Anshor, M. U. (2008). Tantangan Kepemimpinan Perempuan di Tingkat Lokal. Yinyang: Jurnal Studi Islam Gender Dan Anak, 3(1), 81-88. Retrieved from http://ejournal.iainpurwokerto.ac.id/index.php/yinyang/article/view/189

Anthony, S. G., \& Antony, J. (2017). Academic Leadership-Special or Simple. International Journal of Productivity and Performance Management, 66(5), 630-637. https://doi.org/10.1108/IJPPM-08-2016-0162

Asmara, A. (2020). Kekuasaan Perempuan: Studi Terhadap Kepemimpinan di Desa Sumbermulyo Kecamatan Bambanglipuro Kabupaten Bantul. Skripsi: Sekolah Tinggi Pembangunan Masyarakat Desa “APMD” Yogyakarta.

Baharun, H., Wibowo, A., \& Hasanah, S. N. (2021). Kepemimpinan Perempuan Dalam Menciptakan Sekolah Ramah Anak. Quality, 9(1), 87-102. https://doi.org/10.21043/quality.v9i1.10109

Behrendt, P., Matz, S., \& Göritz, A. S. (2017). An Integrative Model of Leadership Behavior. The Leadership Quarterly, 28(1), 229-244. https://doi.org/10.1016/j.leaqua.2016.08.002

Bendell, B. L., Sullivan, D. M., \& Marvel, M. R. (2019). A Gender-Aware Study of SelfLeadership Strategies Among High-Growth Entrepreneurs. Journal of Small Business Management, 57(1), 110-130. https://doi.org/10.1111/jsbm.12490

By, R. T. (2021). Leadership: In Pursuit of Purpose. Journal of Change Management, 21(1), 30-44. https://doi.org/10.1080/14697017.2021.1861698

Cheong, M., Yammarino, F. J., Dionne, S. D., Spain, S. M., \& Tsai, C.-Y. (2019). A Review of the Effectiveness of Empowering Leadership. The Leadership Quarterly, 30(1), 3458. https://doi.org/10.1016/j.leaqua.2018.08.005

Cherneski, J. (2020). Evidence-Loving Rock Star Chief Medical Officers: Female Leadership Amidst COVID-19 in Canada. Gender, Work \& Organization, 27(5), 900913. https://doi.org/10.1111/gwao.12494

Da Meisa, E. A., \& Anzari, P. P. (2021). Perspektif Feminisme Dalam Kepemimpinan Perempuan di Indonesia. Jurnal Integrasi dan Harmoni Inovatif Ilmu-Ilmu Sosial, 1(6), 711-719. https://doi.org/10.17977/um063v1i62021p711-719

Emanratu, P. F. (2021). Kepemimpinan Perempuan Dalam Perspektif Masyarakat Desa. Jurnal OTONOMI - STIA TRINITAS, 13(25), 1-8. DOI: 10.31219/osf.io/2hb36

Ferta, R. R. (2020). Kapabilitas Kepemimpinan Kepala Desa Perempuan di Desa Ganting Kecamatan Salo Kabupaten Kampar Perspektif Fiqh Siyasah". Skripsi: Universitas Islam Negeri Sultan Syarif Kasim Riau. https://repository.uinsuska.ac.id/27657/

Ford, J., Harding, N. H., Gilmore, S., \& Richardson, S. (2017). Becoming the Leader: Leadership as material presence. Organization Studies, 38(11), 1-19. https://doi.org/10.1177/0170840616677633

Gardner, W. L., Karam, E. P., Alvesson, M., \& Einola, K. (2021). Authentic leadership theory: The case for and against. The Leadership Quarterly, 101495. https://doi.org/10.1016/j.leaqua.2021.101495

Garfield, Z. H., Hubbard, R. L., \& Hagen, E. H. (2019). Evolutionary Models of Leadership:

103 | Journal of Local Government Issues (LOGOS), 4 (2), September 2021, pp 90105

ISSN : 2620-8091 print | 2620-3812 online 
Tests and Synthesis. Human Nature., 30, 23-58. https://doi.org/10.1007/s12110019-09338-4

Hamka, H. (2016). Kepemimpinan Perempuan dalam Era Modern. Al-Qalam, 19(1), $107-$ 116. http://dx.doi.org/10.31969/alq.v19i1.222

Handayani, I. (2021). Indonesia Peringkat Keempat Negara dengan Pemimpin Perempuan Terbanyak di Dunia. https://www.beritasatu.com/politik/766447/indonesia-peringkat-keempatnegara-dengan-pemimpin-perempuan-terbanyak-di-dunia

Harmer, E., Savigny, H., \& Ward, O. (2017). 'Are You Tough Enough?'Performing Gender in the UK leadership Debates 2015. Media, Culture \& Society, 39(7), 960-975. https://doi.org/10.1177/0163443716682074

Haryanti, R. (2019). Menteri Perempuan Lebih Sedikit, Ini Kata Peneliti Politik LIPI, https://www.kompas.com/tren/read/2019/10/25/211625865/menteriperempuan-lebih-sedikit-ini-kata-peneliti-politik-lipi.

Kakabadse, N. K., Tatli, A., Nicolopoulou, K., Tankibayeva, A., \& Mouraviev, N. (2018). A Gender Perspective on Entrepreneurial Leadership: Female Leaders in Kazakhstan. European Management Review, 15(2), 155-170. https://doi.org/10.1111/emre.12125

Louis, K. S. (2015). Linking Leadership to Learning: State, District and Local Effects. Nordic Journal of Studies in Educational Policy, 2015(3), 7-17. https://doi.org/10.3402/nstep.v1.30321

Lunenburg, F. C. (2010). The Decision Making Process. Paper presented at the National Forum of Educational Administration \& Supervision Journal.

Muhajir, M. (2019). Kepemimpinan Perempuan Dalam Islam. Al-Qadha, 5(2), 9-19. https://doi.org/10.32505/qadha.v5i2.1273

Newsome, L. (2017). Female Leadership and Welfare State Reform: The development of Australia's First National Paid Parental Leave Scheme. Australian Journal of Political Science, 52(4), 537-549. https://doi.org/10.1080/10361146.2017.1359490

Nursholikah, I. (2016). Analisis Kepemimpinan Kepala Desa Perempuan Dalam Meningkatkan Pelayanan Masyarakat. Jurnal Civic Hukum, 1(2), 74-83. https://doi.org/10.22219/jch.v1i2.10623

Ospina, S. M., Foldy, E. G., Fairhurst, G. T., \& Jackson, B. (2020). Collective Dimensions of Leadership: Connecting Theory and Method. Human Relations, 73(4), 441-463. https://doi.org/10.1177/0018726719899714

Post, C., Latu, I. M., \& Belkin, L. Y. (2019). A Female Leadership Trust Advantage in Times Of Crisis: Under What Conditions? Psychology of Women Quarterly, 43(2), 215-231. https://doi.org/10.1177/0361684319828292

Prasetiawan, A. Y., \& Lis, S. (2019). Kepemimpinan Perempuan dalam Pesantren. Yinyang: Jurnal Studi Islam Gender Dan Anak, 14(1), 39-69. https://doi.org/10.24090/yinyang.v14i1.2874

Pratiwi, A. M. (2019). The Policies, Practices, and Politics of Women Representation in Political Parties: A Case Study of Women Members of Parliament in Regency/Citylevel Legislative Council Period 2014-2019. Jurnal Perempuan, 24(2), 151-163.

104 | Journal of Local Government Issues (LOGOS), 4 (2), September 2021, pp 90 105

ISSN : 2620-8091 print | 2620-3812 online 
Rosenhead, J., Franco, L. A., Grint, K., \& Friedland, B. (2019). Complexity Theory and Leadership Practice: A Review, A Critique, and Some Recommendations. The $\begin{array}{lll}\text { Leadership } \quad \text { Quarterly, } & 101304 .\end{array}$ https://doi.org/10.1016/j.leaqua.2019.07.002

Rudolph, C. W., Katz, I. M., Ruppel, R., \& Zacher, H. (2020). A Systematic and Critical Review of Research on Respect in Leadership. The Leadership Quarterly, 101492. https://doi.org/10.1016/j.leaqua.2019.101335

Saputra, K., \& Azmi, A. (2021). Kepemimpinan Kepala Desa Perempuan. Journal of Civic Education, 4(1), 57-65. http://jce.ppj.unp.ac.id/index.php/jce/article/view/464

Sari, Y. P. (2021). Peran Kepemimpinan Kepala Desa Perempuan Dalam Pembangunan Desa di Desa Banjarsari Kecamatan Ngajum Kabupaten Malang. Skripsi: Universitas Negeri Malang.

Sihidi, I., Khanifah, L., \& Romadhan, A. (2019). The Politics of Gender in Indonesia's Political Parties. Paper presented at the Third International Conference on Sustainable Innovation 2019-Humanity, Education and Social Sciences (IcoSIHESS 2019). https://doi.org/10.2991/icosihess-19.2019.62

Sugiyono. (2017). Metode Penelitian Kuantitatif, Kualitatif, dan R\&D. Bandung: Alfabeta.

Sumenep, P. K. (2020). Perempuan Menjadi Indikator Kemajuan Ibu Pertiwi. Madura: Sumenep Kab.go.id. http://sumenepkab.go.id/berita/baca/nia-kurniaperempuan-menjadi-indikator-kemajuan-ibu-pertiwi-

Utaminingsih, A., Sabariman, H., \& Riniwati, H. (2020). Representasi Feminisme Pada Kepemimpinan Perempuan Di Madura (Studi Keberhasilan Kepala Desa Perempuan Menjadikan Desa Bunder Sebagai Desa Swakarya Dan Desa Swasembada). Kafaah: Journal of Gender Studies, 10(2), 173-186. http://dx.doi.org/10.15548/jk.v\%25vi\%25i.347

Yuki, G. (2010). Kepemimpinan dalam Organisasi, edisi kelima. Jakarta: PT. Indeks.

Zakiah, S. (2018). Kepemimpinan Perempuan Pada Madrasah Aliyah di Kabupaten Bone. Al-Maiyyah: Media Transformasi Gender dalam Paradigma Sosial Keagamaan, 11(1), 30-64. https://doi.org/10.35905/almaiyyah.v11i1.543 